\title{
А. РАСУЛОВ
}

\section{СОСТОЯНИЕ И ПЕРСПЕКТИВЫ УРЕГУЛИРОВАНИЯ СИТУАЦИИ В АФГАНИСТАНЕ}

Азиз Расулов, руководитель проекта Института стратегических и межрегиональных исследований при Президенте Республики Узбекистан.

\begin{abstract}
Аннотация
Анализируется развитие афганского кризиса в условиях вывода войск коалиции и риски внутриполитического процесса. Мирный транзит власти в стране обнадеживает, однако страна продолжает оставаться эпицентром терроризма и наркотрафика. Активизация вооруженной оппозиции заставляет задуматься о сроках вывода иностранных войск. Подчеркнута необходимость международной экономической помощи Афганистану и переговоров с Талибаном без предварительных условий.
\end{abstract}

Ключевые слова: афганский кризис, Центральная Азия, терроризм, наркотрафик, транзит власти, консенсус, Талибан, США, Исламское государство.

Урегулирование афганского кризиса продолжает оставаться одной из актуальнейших проблем современности. В течение многих лет данный вопрос затрагивает интересы не только самого Афганистана или его соседей, но и влияет на общий фон глобальной безопасности. Продолжающаяся более 35 лет война оказывает непосредственное негативное воздействие практически на все ключевые политико-экономические процессы в Центральной Азии, являясь одним из главных дестабилизирующих факторов в регионе.

Сегодня высказываются различные предположения и прогнозы относительно возможных сценариев развития ситуации в Афганистане, влияния этих процессов на приграничные государства. Но все практически едины во мнении: страна продолжает оставаться эпицентром и источником терроризма, экстремизма и наркотрафика. Ситуация усугубляется растущей милитаризацией, внутриполитической нестабильностью, неутешительными перспективами экономики Афганистана, геополитическим соперничеством крупных держав, а также эскалацией вооруженного противостояния на Ближнем Востоке.

Несмотря на предпринимаемые меры со стороны международного сообщества и афганского правительства, ситуация во многих районах Афганистана остается неконтролируемой, сложная военно-политическая обстановка приобрела перманентный характер.

Следует признать, что процесс поэтапного вывода войск ISAF привел к активизации деятельности вооруженной оппозиции практически на всей территории Афганистана, став причиной очередного витка обострения противостояния в этой стране. Указанные тенденции несут потенциальные риски и вызовы для Центрально-Азиатского региона, в том числе в плане роста «ползучего» радикального экстремизма.

Как наглядно свидетельствует опыт Ирака, любой образовавшийся вакуум в стране может за короткое время заполниться различными экстремистскими и террористическими группировками, способными распространить свое разрушительное влияние на обширные территории.

В этих непредсказуемых условиях нельзя исключить попытки отдельных политических сил при поддержке внешних факторов посеять хаос и еще более усугубить положение в Афганистане. Кроме того, нередко вовлеченные страны, преследуя собственные интересы, приходят в Афганистан со «своей повесткой дня», стараясь по максимуму извлечь для себя выгоду из своего участия в деле афганского урегулирования. Как показывает история Афганистана последних двух столетий, это заведомо неконструктивный и тупиковый путь, более того, несущий в себе угрозы окружающим государствам. 
В этих условиях, на наш взгляд, самый главный принцип урегулирования заключается в том, что проблемы Афганистана должны решаться непосредственно самими афганцами при всесторонней поддержке международного сообщества.

Чрезвычайно важно продолжить оказание целенаправленной экономической помощи Афганистану, строительство и формирование экономической и социальной инфраструктуры, обеспечение занятости населения, решение острейших проблем борьбы с бедностью. К сожалению, до сих пор, несмотря на проведение многочисленных конференций, принятие программ развития и обязательств оказания международной помощи, усилия мирового сообщества на этом направлении носят половинчатый характер и не всегда достигают поставленных целей.

Хотел бы обратить внимание на ряд интересных тенденций, произошедших за последнее время в Афганистане. Указанные процессы потенциально могут иметь важные и в некоторых случаях даже судьбоносные последствия как для самого Афганистана, так и для сопредельных с ним государств и регионов, а также интересов ключевых внешних сил, вовлеченных в процесс урегулирования ситуации в стране.

Во-первых, впервые в истории афганской государственности произошел мирный транзит власти, что потенциально предоставляет Афганистану новые возможности для достижения долгосрочной стабильности. Итоги президентских выборов, состоявшихся в прошлом году, наглядно продемонстрировали, что афганский народ устал от бесконечного кровопролития и насилия, многолетней нищеты и разрухи и сегодня желает мира и стабильности, иметь право самому определять свою судьбу. Однако этот процесс не проходит гладко, возникают различного рода противоречия и конфликт интересов.

Тем не менее мы абсолютно убеждены в том, что только скорейшее завершение путем поиска компромиссов процессов формирования нового правительства Афганистана, где были бы представлены противоборствующие политические и этно-религиозные силы, может проложить дорогу к снижению уровня нестабильности, ликвидации нищеты, восстановить разрушенную экономику, обеспечить мир и спокойствие в стране.

Во-вторых, по информации ведущих зарубежных СМИ, новые власти Афганистана планируют начать переговоры с лидерами Движения Талибан. Республика Узбекистан неоднократно заявляла, что единственно разумный путь выхода из этого кризиса - это поиск политического урегулирования проблемы путем мирных переговоров и достижения консенсуса между различными противоборствующими сторонами.

В то же время считаем контрпродуктивным ставить договаривающимся сторонам какие-то предварительные условия, которые могут не только затянуть переговорный процесс, но и вновь вернуть к эскалации напряженности и продолжению противоборства.

В-третьих, согласно заявлениям высокопоставленных чиновников американской администрации, США изучают возможность сохранения в Афганистане армейского контингента - более масштабного, чем предусматривается планами сокращения. Министр обороны США Эштон Картер пояснил, что «пересмотр замыслов Вашингтона объясняется стремлением надежнее закрепить результаты, достигнутые в ходе американской военной операции».

Мы убеждены, что форсирование процессов вывода войск ISAF может привести к обратным результатам, то есть к эскалации напряженности, еще большей активизации террористических сил. Прогнозируется, что в случае развития событий по негативному сценарию возникнет прямая угроза попадания вооружения афганской армии в руки региональных группировок и террористических структур, что мы уже наблюдали после вывода советских войск.

В-четвертых, вызывают озабоченность сообщения об активизации деятельности эмиссаров так называемого «Исламского государства» на территории Афганистана. Глава миссии НАТО в Афганистане Джон Кемпбелл указал на случаи «переименования талибских отрядов, пытающихся использовать в своих интересах известность нового движения» и сообщил, что разведывательные структуры США продолжают следить за потенциаль- 
ной угрозой расширения присутствия «Исламского государства» на территории Афганистана.

В этой связи, большинство наблюдателей не исключает, что рост «идеологических», тактических и иных противоречий между ИГ и движением Талибан потенциально способно привести к активизации афганских приверженцев «глобального джихада» в южных регионах страны с дальнейшим смещением их террористической деятельности в северном направлении.

Данное обстоятельство ставит перед странами региона задачи по дополнительному укреплению собственной безопасности, что отвлекает значительные материальные и физические ресурсы, необходимые для осуществления мер по дальнейшему развитию и модернизации национальных экономик, решения насущных социально-экономических проблем, развитию межрегиональных связей, а также реализации перспективных транспортно-инфраструктурных проектов.

В завершение хотелось бы подчеркнуть, что мы в Узбекистане отчетливо осознаем, что достижение мира и стабильности в Афганистане является важным фактором региональной безопасности, открывающим большие возможности для решения жизненно важных проблем устойчивого социально-экономического развития всех государств и народов, проживающих в обширном регионе Центральной и Южной Азии.

Мы выражаем поддержку усилиям афганского народа по национальному примирению, мирному восстановлению, возрождению страны, выступаем за укрепление центральной координирующей роли ООН в международных условиях по афганскому урегулированию посредством широкого использования политико-дипломатических методов и инструментов.

\section{STATUS AND OUTLOOK FOR RECONCILIATION OF SITUATION IN AFGHANISTAN}

Aziz Rasulov, Project Lead at the Center for Strategic and Inter-Regional Studies under the President of the Republic of Uzbekistan.

\footnotetext{
Summary

The article describes the possibilities of SCO expansion and its transformation from regional to global structure. The SCO development strategy and actual needs of organization are analyzed.The main attention is paid to Afghanistan and Iran. The ways of overcoming disproportions between political and economic activities within SCO are submitted for consideration.
}

Key words: Afghan crisis, Central Asia, terrorism, drugs trafficking, transit of power, consensus, Taliban, USA, Islamic State. 